\title{
Resistance Mechanisms of Peltophorum dubium (Sprengel) Taubert Submitted to Flood Conditions
}

\author{
Lara Siqueira Oliveira Carvalho ${ }^{1}$, Jean Marcel Sousa Lira ${ }^{1}$, \\ Amanda Cristiane Rodrigues ${ }^{2}$, Túlio Silva Lara ${ }^{1}$, Fernanda Ventorim Pacheco ${ }^{3}$, \\ Amauri Alves de Alvarenga
}

\footnotetext{
${ }^{1}$ Departamento de Biologia, Setor de Fisiologia Vegetal, Universidade Federal de Lavras - UFLA, Lavras/MG, Brasil ${ }^{2}$ Faculdade de Ciências e Linguagens, Instituto Federal de Minas Gerais, Bambuí/MG, Brasil ${ }^{3}$ Departamento de Agricultura, Universidade Federal de Lavras - UFLA, Lavras/MG, Brasil
}

\begin{abstract}
Peltophorum dubium (Sprengel) Taubert seedlings were submitted to 60 days of flooding, with and without $\mathrm{Ca}^{+}$. During this period, growth, root anatomy and chlorophyll content were analyzed. The relative growth rates (RGR) of roots and shoots were higher in non-flooded plants. The flooded treatments, with and without $\mathrm{Ca}^{+}$, have affected the roots growth but did not affect the shoot and the stem diameter. The anatomy analysis showed thickening of the sclerenchyma in 15 and 60 days in the flooded treatments with and without $\mathrm{Ca}^{+}$, and the vessel diameter was smaller at 45 days. The chlorophyll content differed, however it was not statistically significant. The results indicate that Peltophorum dubium as candidate specie for reforestation in areas subjected to continuous flooding for up to 60 days, since no mortality was observed.
\end{abstract}

Keywords: angico amarelo, calcium application, flooded environments.

\section{Mecanismos de Resistência de Peltophorum dubium (Sprengel) Taubert Submetido a Condições de Alagamento}

\begin{abstract}
RESUMO
Mudas de Peltophorum dubium (Sprengel) Taubert foram submetidas a 60 dias de alagamento, com e sem a aplicação de cálcio. Durante esse período, foram avaliados: crescimento, anatomia radicular e teor de clorofila. As taxas de crescimento relativo (TCR) de raiz e parte aérea foram maiores nas plantas não alagadas. O alagamento, com e sem aplicação do cálcio, afetou negativamente o comprimento das raízes, mas isso não afetou a parte aérea e o diâmetro do caule. As análises anatômicas mostraram aumento na espessura do esclerênquima nos tratamentos alagado e alagado $+\mathrm{Ca}^{+}$aos 15 e 60 dias, e o diâmetro dos vasos foi menor aos 45 dias. Nos teores de clorofila foram registradas diferenças entre os tratamentos, porém não foram diferenças estatisticamente significativas. Os resultados indicam que a Peltophorum dubium é espécie candidata para reflorestamento em áreas sujeitas a alagamento contínuo por até 60 dias, uma vez que não foi observada mortalidade.
\end{abstract}

Palavras-chave: angico amarelo, aplicação de cálcio, ambientes alagados. 


\section{INTRODUCTION}

The Brazilian Forest Code defines areas of rivers or any water course as permanent preservation areas (Brasil, 2012). However, these areas have been constantly modified and even destroyed, causing ecosystems fragmentation and degradation. Usually, the most devastated areas are the watershed areas, especially due to anthropic activities (Gonçalves, 2009). The recovery of areas susceptible to flooding is difficult and selective. In order to plan the recovery of watershed areas, it is necessary to study species that are tolerant to flooding conditions for at least a determined period of the year.

Plants growing in flooded areas need to tolerate hypoxic conditions, which characterize an ambient poor in oxygen and consequently with a low availability of this element to the roots. Species under hypoxic conditions respond with different efficiency to flooding conditions, given that some are tolerant while others are intolerant to the low availability of oxygen (Dalmoli, 2009).

Hypoxic tolerant species are able to develop anatomic and biochemistry characteristics that allow these plants to survive in particular environments. The presence of lenticels, aerenchym and adventitious roots are usually found as modifications to facilitate the diffusion of oxygen to the roots. The aerobic respiration and chlorophyll content help to maintain the basic processes, such as photosynthesis. These processes provide energy, even if in a small amount, to keep the cells running. Most species tend to combine anatomic and biochemistry adjustment to tolerate flooding conditions.

Although the processes which define species as tolerant or not to flooding conditions are well known, it's still unclear how these processes are activated and how they drive the plant physiology to induce tolerance. The calcium, for example, can act as secondary messenger at the perception of oxygen deficit (Dantas et al., 2001). It also acts as a structural element of the cell walls, participating at the covalent bond between carboxylic groups of poligalacturonics acid and it is related to modifications at the metabolism of cell walls (Melo et al., 2004).

Peltophorum dubium (Sprengel) Taubert (Fabaceae) is known as angico amarelo, and occurs in watersheds and wetlands, therefore is a tolerant species able to have its roots under water for certain periods of the year
(Salvador, 1989). Thus, Peltophorum dubium can be used to the recovery of degraded wetlands. For being common in flooded areas, this species could also be a good model for anatomic and biochemistry studies to understand the flooding tolerance. Besides, it consist in a species with a fast growth rate and rusticity, characteristics that are desirable for species used in reforestation (Lorenzi, 1992).

This paper aimed to verify the effects of $\mathrm{Ca}^{+}$at the flooding tolerance of Peltophorum dubium, with the purpose of using this species to the recovery of wetlands areas, especially areas of natural occurrence of this species. We also sought to understand the processes involved at the tolerance of Peltophorum dubium to flooding conditions.

\section{MATERIAL AND METHODS}

\subsection{Plant material and conditions}

The experiment was evaluated at a nursery with $30 \%$ of light block at the Biology Department/Vegetal Physiology Sector, located at the Federal University of Lavras in Lavras - MG, Brazil. The seedlings used in the experiments were six months old, and were donated by CEMIG (Minas Gerais Energy Company), produced at their nursery in Itutinga - MG, Brazil, $21^{\circ} 21^{\prime} \mathrm{S}$ and $44^{\circ} 36^{\prime} \mathrm{W}$, altitude of $920 \mathrm{~m}$ (Van Den Berg \& Oliveira-Filho, 2000). The seedlings were transplanted to black polyethylene bags, with two litters capacity, containing substrate of soil and sand in a ratio of 2 to 1 .

The treatments imposed were: flooded without $\mathrm{Ca}^{+}$solution, flooded with $\mathrm{Ca}^{+}$solution and control (not flooded). The seedlings were placed in vases with three liters capacity, which were flooded with water two centimeters above the soil. A solution of $160 \mathrm{ppm}$ calcium chloride $(\mathrm{CaCl})$ was used at the flooded treatment containing $\mathrm{Ca}^{+}$(Johnson et al., 1957), adding about $2,8 \mathrm{ml}$ of a one molar solution per vase.

\subsection{Growth analysis}

The data were collected during 60 days in intervals of $0,15,30,45$ and 60 days. The root length, based on the bigger root, and the shoot length were evaluated with a $30 \mathrm{~cm}$ ruler $( \pm 0.1 \mathrm{~cm})$. The diameter of the stem was measured using a caliper, and the measurements were taken $2 \mathrm{~cm}$ above the soil. Roots and shoots 
collected for growth analyses were dried at an oven at $70{ }^{\circ} \mathrm{C}$ for 72 hours. After this period the dried material was weighted in analytical balance with a precision of $0.01 \mathrm{~g}$. The relative growth rates (RGR) of the roots and shoot were calculated by the formula: $\mathrm{RGR}=(\operatorname{lnDMf}-\ln \mathrm{lni}) /\left(\mathrm{t}_{\mathrm{f}}-\mathrm{t}_{\mathrm{i}}\right)$ (where the log $=$ natural logarithm, DMf $=$ dry mass final, $\mathrm{DMi}=$ dry mass initial, $\mathrm{t}_{\mathrm{f}}=$ final time and $\mathrm{t}_{\mathrm{i}}=$ initial time). The software Aob Tool (Hunt et al., 2002) was used to calculate the RGR at day 0 and at 60 days.

\subsection{Biochemistry and anatomical analysis}

For the chlorophyll analysis fully expanded leaves were used. The leaves were excised and wrapped in aluminum foil and were kept in ice until extraction. For the extraction $0.4 \mathrm{~g}$ of fresh leaves were macerated in $5 \mathrm{~mL}$ of an $80 \%$ acetone solution, which were later on filtered in glass wool. After filtering, the volume of the extract was completed to $10 \mathrm{~mL}$ and was read in a spectrophotometer, in wave lengths of 663.2 and $646.2 \mathrm{~nm}$. All the process was performed in a room illuminated with green lights in order to avoid chlorophyll degradation. Three repetitions were conducted for each treatment and each repetition was read three times.

To evaluate the anatomical parameters samples of the roots were collected and kept in a 70\% ethanol solution (Johansen, 1940). The transversal sections of the roots were made at the Vegetal Anatomy Laboratory of the Biology Department/UFLA using a microtome table (LPC model), taking the sections $1 \mathrm{~cm}$ above the root cap of the main root. In the sequence, the sections were clarified with a $50 \%$ solution of sodium hypochlorite then, they were washed in distilled water, dyed with a safra-blau solution (safranin 1\% and astra blue $0.1 \%$ ) and set up in a semi-permanent slide with 50\% glycerin (Kraus \& Arduin, 1997). The measurements were evaluated at the software Image tool version 3.0 (Wilcox et al., 2002).

\subsection{Statistical analysis}

The experiment was evaluated in a factorial $3 \times 5$ entirely casual design, with application of three conditions for the seedlings (flooded without $\mathrm{Ca}^{+}$, flooded with $\mathrm{Ca}^{+}$ and control) and five periods (0, 15, 30, 45, 60 days). Five seedlings were used for each growth analysis and three seedlings for each anatomical analysis. Thus, for day zero, 8 seedlings were used (just control plants) and in the follow evaluations it was used 24 seedlings, totalizing 104 seedlings for the whole experiment. The leaves used for chlorophyll analysis were collected from the same seedlings used for anatomical analysis. The statistical analysis were proceeded using the software SISVAR version 5.3 (Ferreira, 1999) and the averages were compared using the Scott-Knott test $(\mathrm{p}<0,05)$.

\section{RESULTS AND DISCUSSION}

The experiment was evaluated during 60 days and mortality was not observed, though necrosis of the roots was observed (Figure 1). However, it was observed the emergence of adventitious roots, which probably ensured the survival of the plants.

The flooding promoted an increase at the sclerenchyma thickness at 15 and 60 day-period, in the treatments with and without $\mathrm{Ca}^{+}$when compared to the control. The increase at the sclerenchyma thickness was not different at the flooded conditions with or without $\mathrm{Ca}^{+}$, as shown in Table 1 .

The sclerenchyma is a sustaining tissue with thick secondary walls, usually lignified and with hydrophobic cells, making the transition of the water through the wall very slow avoiding root drowning (Appezzato-da-Glória \& Carmello-Guerreiro, 2006).

At the 45 day-period, it was observed differences at the vessels among the flooded treatments and the control. The flooded plants with and without $\mathrm{Ca}^{+}$, exhibited smaller vessels diameter compared to the control plants (Table 1). The smaller vessel diameter in flooded plants difficult the formation of bubbles inside the vessels, which could cause embolisms and block the water flow. The maintenance of the water flow is important once the flood might reduce the water absorption (Coutts, 1981; Batista et al., 2008).

Although mortality wasn't observed, it was seen a decrease in the growth rates on the flooded plants, either with $\mathrm{Ca}^{+}$or without $\mathrm{Ca}^{+}$(Table 2).

Both RGR, roots and shoot, at the flooding conditions showed a similar behavior, however with a significant difference between the flooded treatments and the control. Batista et al. (2008) observed in Cecropia pachystachya, after 30 days of flood, partial death of the roots and emergence of adventitious roots, being these new roots a sign of tolerance to flooding conditions.

The addition of $\mathrm{Ca}^{+}$did not promote any effect for the flooding condition. Instead, it was observed 

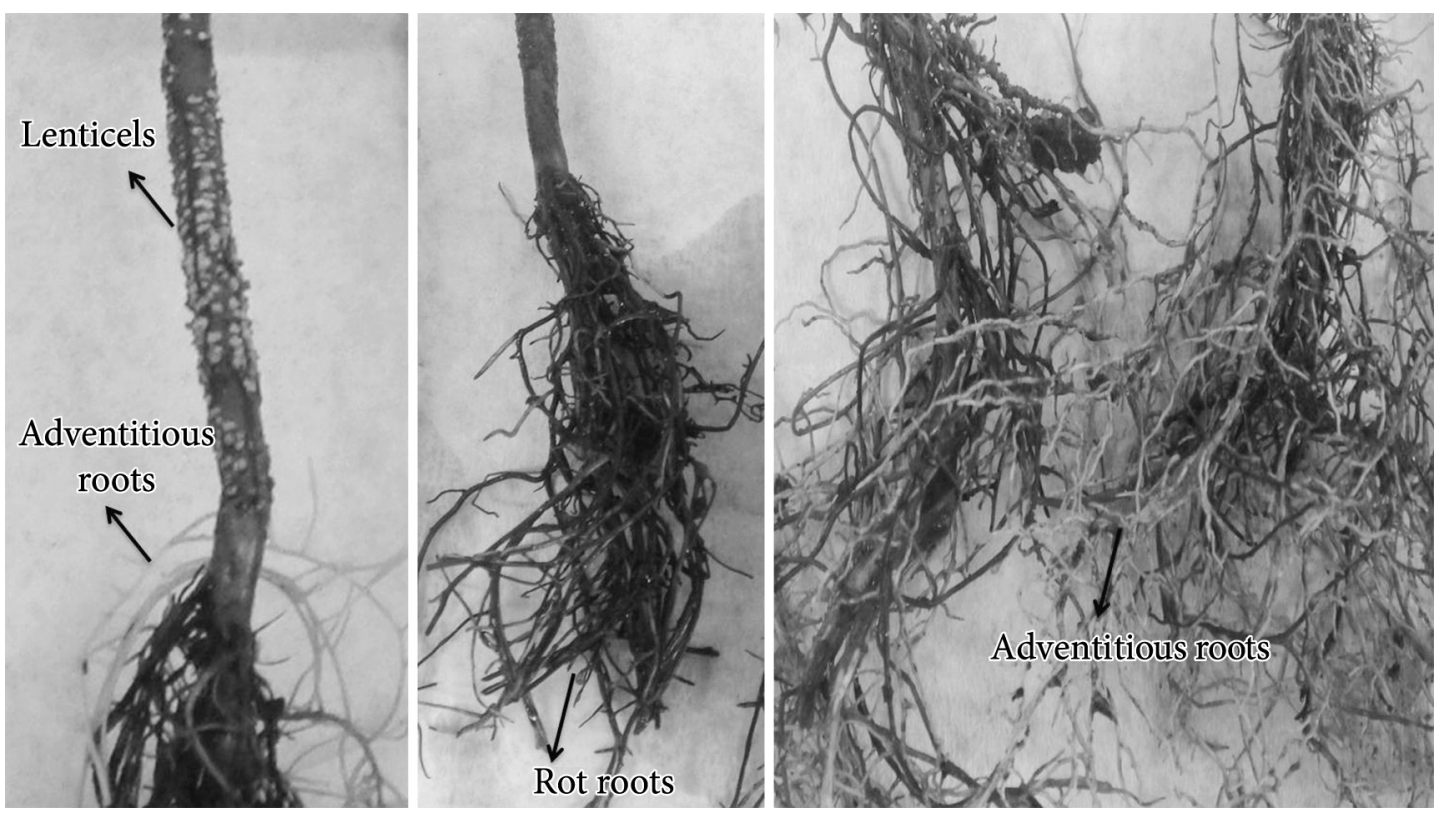

Figure 1. Details of the lenticels, root necrosis and formation of new roots in Peltophorum dubium under flooding conditions. The arrows indicate the main points observed at the results.

Figura 1. Detalhes das lenticelas, necroses radiculares e formação de novas raízes em Peltophorum dubium sob condições de alagamento. As setas indicam os principais pontos observados nos resultados.

Table 1. Sclerenchyma thickness and diameter of the vessels of Peltophorum dubium flooded without $\mathrm{Ca}^{+}$, flooded with $\mathrm{Ca}^{+}$and control.

Tabela 1. Espessura do esclerênquima e diâmetro dos vasos de Peltophorum dubium alagado sem cálcio, alagado com $\mathrm{Ca}^{+}$e controle.

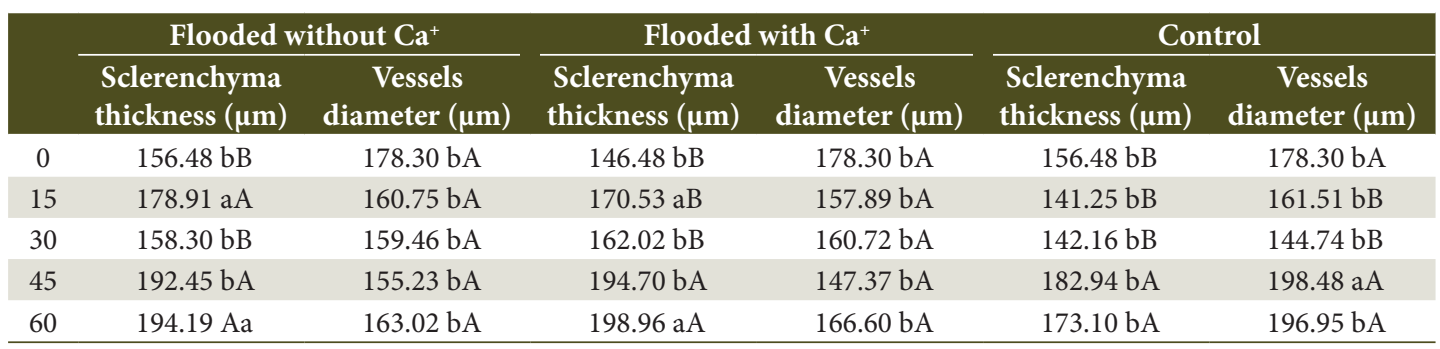

Means followed by the same small letter in the line, for treatments, and means followed by the same capital letter in the column, for flooding time, do not differ (Scott-Knott, $\mathrm{P}<0.05$ ).

Table 2. (RGR) of roots and shoot of Peltophorum dubium flooded without $\mathrm{Ca}^{+}$, flooded with $\mathrm{Ca}^{+}$and control, after 60 days of treatments.

Tabela 2. Taxa de Crescimento Relativo (TCR) de raízes e parte aérea de Peltophorum dubium alagado sem cálcio, alagado com $\mathrm{Ca}^{+}$e controle, depois de 60 dias dos tratamentos.

\begin{tabular}{lcc}
\multicolumn{1}{c}{ Treatments } & Roots RGR & Shoot RGR \\
\hline Flooded without $\mathrm{Ca}^{+}$ & $0.006 \mathrm{~b}$ & $0.004 \mathrm{~b}$ \\
Flooded with $\mathrm{Ca}^{+}$ & $0.002 \mathrm{~b}$ & $0.002 \mathrm{~b}$ \\
\hline Control & $0.014 \mathrm{a}$ & $0.010 \mathrm{a}$ \\
\hline
\end{tabular}

Means followed by the same letter do not differ (Scott-Knott, $\mathrm{P}<0.05)$. smaller values of RGR in this condition (Table 2). It was observed that the plants flooded with $\mathrm{Ca}^{+}$had an intense leaf abscission and a consequently loss of biomass, which could explain why these plants exhibited a lower RGR.

Medri et al. (2012) also observed in flooded plants of Aegiphila sellowiana the leaf abscission. This behavior might be associated to the process of programmed cell death signaled by the $\mathrm{Ca}^{+}$, stimulating the production of ethylene which will induce leaf abscission (Drew et al., 2000). Batista et al. (2008) showed a decrease in growth 
of some organs during flooded treatments. This could be a plant strategy to save energy and maintain the metabolism at a minimum level in order to avoid plant mortality, or could also be a simple consequence of low production of ATPs (adenosine triphosphate). Kozlowski (1997) associated the decrease in the roots growth with low levels of energy created in hypoxic environments.

The reduced growth of the roots in flooded plants may be explained because in the flooded soils, rot of the roots can occur as result of fungus activity in the soil, which could lead to necrosis affecting the root growth (Figure 2). The decrease in roots growth was also observed by Batista et al. (2008) in flooded plants of C. pachystachya.

The shoot length increased by approximately $20 \%$ at the first 15 days for all treatments. As for the next time periods the length was more constant, with no significant differences among the treatments (Figure 2). The higher shoot growth value was observed at the 15 first days, suggesting that this increase in length was an answer to the flooding condition. This answer could be a way to maintain the leaves above the water level (Batista, 2008), which was probably caused by the ethylene production.

The stem diameter showed an average of $25 \%$ increase for all treatments in the first 15 days. After this period, the stem diameter remained constant for all the treatments. No differences were observed at the statistics (Figure 2). This could be explained by the fact that in hypoxic soils the growth is maintained depending on the nutritional condition of the plants and also depending on the time that the plants remain flooded (Santiago \& Paoli, 2003).

At the flooded seedlings it was observed hypertrophy of lenticels at the lower part of the stem (Figure 1).
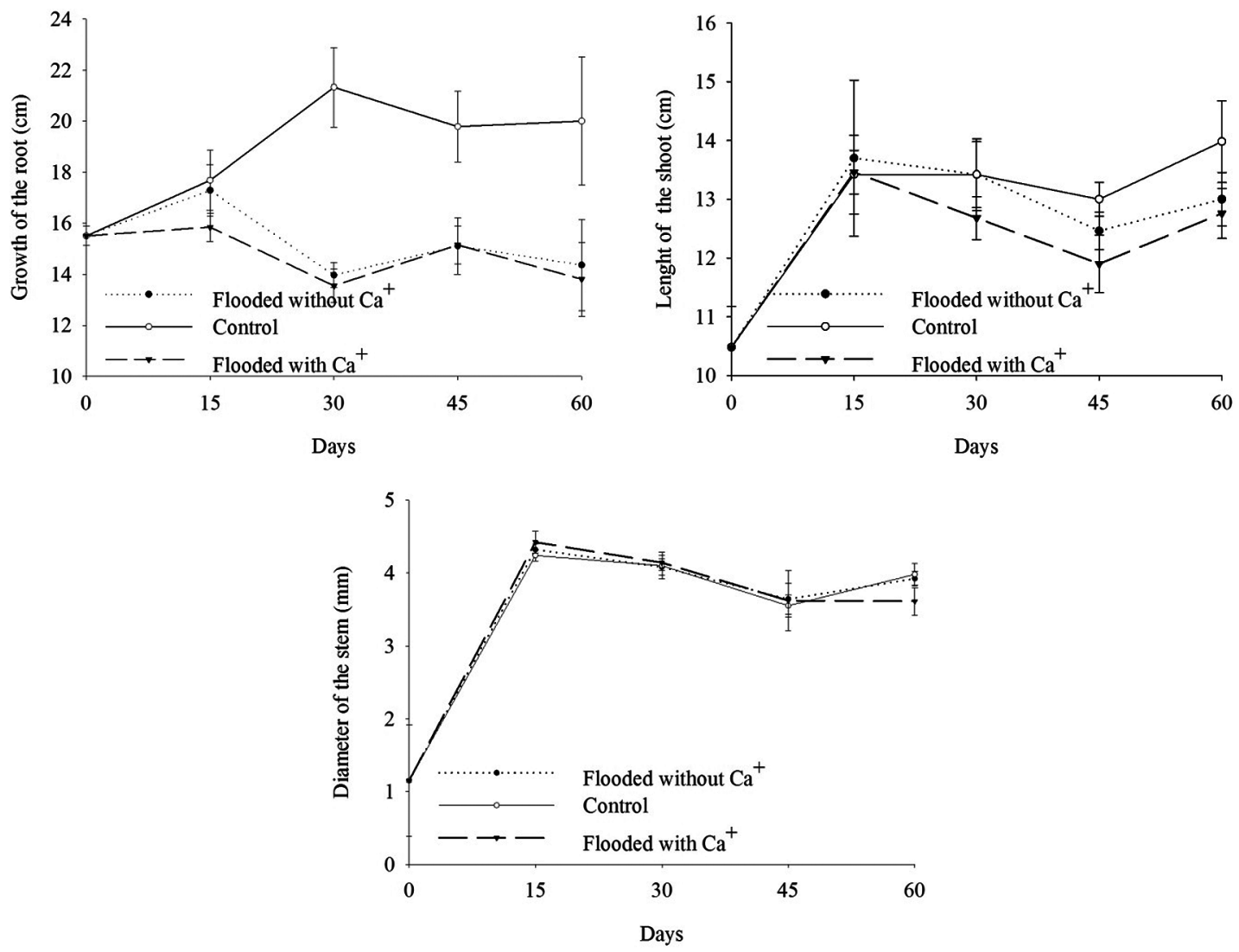

Figure 2. Analyze of root and shoot growth and diameter of the stem of Peltophorum dubium flooded without $\mathrm{Ca}^{+}$, flooded with $\mathrm{Ca}^{+}$and control during the period of $0,15,30,45$ and 60 days. The bars indicate the standard errors. Figura 2. Análise do crescimento da raiz e parte aérea e diâmetro do caule de Peltophorum dubium alagado sem cálcio, alagado com $\mathrm{Ca}^{+}$e controle durante o período de 0,15, 30, 45 e 60 dias. As barras indicam os erros padrões. 


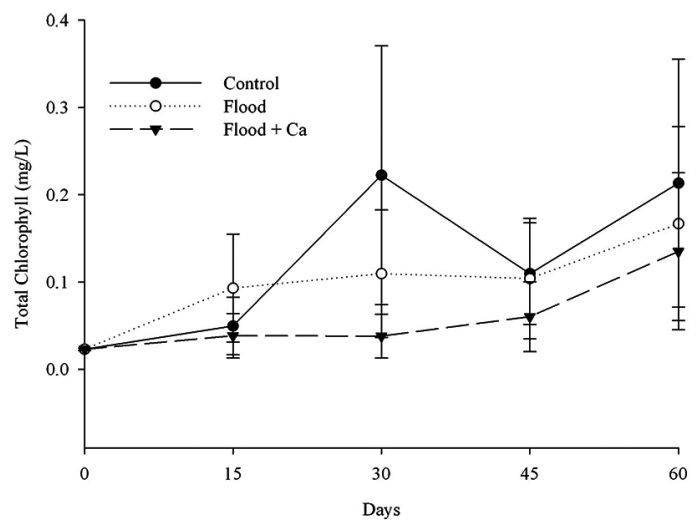

Figure 3. Chlorophyll levels in Peltophorum dubium flooded without $\mathrm{Ca}^{+}$, flooded with $\mathrm{Ca}^{+}$and control during the period of $0,15,30,45$ and 60 days. The bars indicate the standard errors.

Figura 3. Níveis de clorofila em Peltophorum dubium alagado sem cálcio, alagado com $\mathrm{Ca}^{+}$e controle durante o período de $0,15,30,45$ e 60 . As barras indicam os erros padrões.

These lenticels support the survival of the plants during periods of low oxygen availability. The lenticels contribute to oxygen diffusion from the atmosphere to the tissues and also to the release of toxic compounds accumulated during hypoxic periods (Medri et al., 1998).

It was not found any differences at the chlorophyll content. However, the amount of chlorophyll at the 30 day-period for the control plants was superior when compared with the flooded seedlings (Figure 3). At the 45 and 60 day-period it was not found any differences among the control and the flooded seedlings, indicating an acclimation of this species to flooding conditions, once the literature brings Peltophorum dubium as a flooding tolerant plant. The recovery of the photosynthetic pigments might guarantee the survival of Peltophorum dubium in flooded environments. Larré (2011) discussed the effects of flooding at the photosynthesis as a dependence of the partial or total submergences and depending of the time of exposure to the flooding condition.

\section{CONCLUSIONS}

Peltophorum dubium is a tolerant species for at least 60 days under flooding conditions. The anatomic and biochemistry characteristics have shown that Peltophorum dubium is a potential species to be used at the recovery of flooded areas. The $\mathrm{Ca}^{+}$does not potentiate the tolerance aspects of the studied species.

\section{SUBMISSION STATUS}

Received: 1 mar., 2015

Accepted: 8 nov., 2015

\section{CORRESPONDENCE TO}

\section{Lara Siqueira Oliveira Carvalho}

Departamento de Biologia, Setor de Fisiologia Vegetal, Universidade Federal de Lavras - UFLA, Câmpus Universitário, CP 3037, CEP 37200-000, Lavras, MG, Brasil

e-mail: lcarvalho470@gmail.com

\section{REFERENCES}

Appezzato-da-Glória B, Carmello-Guerreiro SM. Anatomia vegetal. 2nd ed. Viçosa: Universidade Federal de Viçosa; 2006.

Batista CUN, Medri ME, Bianchini E, Medri C, Pimenta JA. Tolerância à inundação de Cecropia pachystachya Trec. (Cecropiaceae): aspectos ecofisiológicos e morfoanatômicos. Acta Botanica Brasílica 2008; 22(1): 91-98. http://dx.doi. org/10.1590/S0102-33062008000100012.

Batista TL. Erythrina crista-galli L. (Fabaceae-Faboideae): germinação de sementes, crescimento e morfoanatomia de plântulas submetidas ao alagamento [dissertation]. Rio Grande: Universidade Federal do Rio Grande; 2008.

Brasil. Lei $n^{\circ}$ 12.651, de 25 de maio de 2012. Institui o Novo Código Florestal. Diário Oficial da União [online], Brasília, DF (2012 maio). [cited 2015 Mar 1]. Available from: https://www.planalto.gov.br/ccivil_03/_ato20112014/2012/lei/l12651.htm

Coutts MP. Effect of on waterlogging dormant sitkas pruce seedlings. Annals of Botany 1981; 47: 747-753.

Dalmoli AC. Potencial fotossintético de plantas jovens de cambará (Vochysia divergens Pohl) sob condições de sombra e alagamento [dissertation]. Campo Grande: Universidade Federal de Mato Grosso; 2009.

Dantas BF, Aragão CA, Alves JD. Cálcio e o desenvolvimento de aerênquimas e atividade de celulase em plântulas de milho submetidas a hipoxia. Scientia Agricola 2001; 58(2): 251 257. http://dx.doi.org/10.1590/S0103-90162001000200006.

Drew MC, He CJ, Morgan PW. Programmed cell death and aerenchyma formation in roots. Trends in Plant Science 2000; 5(3): 123-127. http://dx.doi.org/10.1016/ S1360-1385(00)01570-3. PMid:10707078. 
Ferreira DF. Sisvar 4.3: sistema de análises estatísticas. Lavras: UFLA; 1999.

Gonçalves RC. Comparação das alterações morfológicas e de desenvolvimento provocadas pelo alagamento em plantas de seis espécies arbóreas de Leguminoseae [dissertation]. Londrina: Universidade Estadual de Londrina; 2009.

Hunt R, Causton DR, Shipley B, Askew AP. A modern tool for classical plant growth analysis. Annals of Botany 2002; 90(4): 485-488. http://dx.doi.org/10.1093/aob/ mcf214. PMid:12324272.

Johansen DA. Plant microtechnique. New York: McGraw Hill; 1940.

Johnson CM, Stout PR, Broyer TC, Carlton AB. Comparative chlorine requirements of different plant species. Plant and Soil 1957; 8(4): 337-353. http://dx.doi.org/10.1007/ BF01666323.

Kozlowski TT. Responses of woody plants to flooding and salinity. Tree Physiology Monograph 1997; 1(1): 29.

Kraus JE, Arduin M. Manual básico de métodos em morfologia vegetal. Rio de Janeiro: Edur; 1997.

Larré CF. Caracterização morfológica, fisiológica e bioquímica da Corticeira-do-banhado em condições de alagamento [thesis]. Pelotas: Universidade Federal de Pelotas; 2011.

Lorenzi H. Árvores brasileiras: manual de identificação e cultivo de plantas arbóreas nativas do Brasil. Nova Odessa: Plantarum; 1992.

Medri C, Pimenta JA, Ruas EA, Souza LA, Medri OS, Sayhun $\mathrm{S}$ et al. $\mathrm{O}$ alagamento do solo afeta a sobrevivência, o crescimento e o metabolismo de Aegiphila sellowiana
Cham. (Lamiaceae)? Semina: Ciências Biológicas e da Saúde 2012; 33(1): 123-134.

Medri ME, Bianchini E, Pimenta JA, Delgado MF, Correa GT. Aspectos morfoanatômicos e fisiológicos de Peltophorum dubium (Spr.) Taub. submetida ao alagamento e à aplicação de etrel. Revista Brasileira de Botânica 1998; 21(3): 261-267. http://dx.doi.org/10.1590/S0100-84041998000300004.

Melo HC, Castro EM, Romero JL, Alves JD, Fries DD, Melo LA et al. Influência da aplicação de cálcio e alagamento do solo sobre características anatômicas das folhas de milho (Zea mays L.) "Saracura" BRS-4154. Revista Brasileira de Milho e Sorgo 2004; 3(3): 333-342. http:// dx.doi.org/10.18512/1980-6477/rbms.v3n3p333-342.

Salvador JLG. Considerações sobre as matas ciliares e a implantação de reflorestamento misto nas margens de rios e reservatórios. 2nd ed. São Paulo: CESP; 1989.

Santiago EF, Paoli AAS. O aumento em superfície em Adelia membranifolia (Müll. Arg. ) Pax \& K. Hoffm e Peltophorum dubium (Spreng.) Taub., em resposta ao estresse por deficiência nutricional e alagamento do substrato. Brazilian Journal of Botany 2003; 26(4): 503-513. http://dx.doi.org/10.1590/S0100-84042003000400009.

Van Den Berg E, Oliveira-Filho ATO. Composição florística e estrutura fitossociológica de uma floresta ripária em Itutinga, MG, e comparação com outras áreas. Brazilian Journal of Botany 2000; 23(3): 231-253. http://dx.doi. org/10.1590/S0100-84042000000300002.

Wilcox D, Dove B, Mcdavid D, Greer D. Image Tool. Versão 3.0. San Antonio: Health Science Center, University of Texas; 2002 